\title{
Geology of the Jolon and Williams Hill Quadrangles Monterey County, California
}

$A$ study of stratigraphy and structure of Cenozoic sedimentary rocks in part of the Salinas Valley

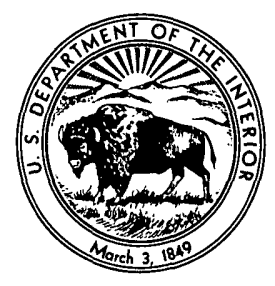




\title{
UNITED STATES DEPARTMENT OF THE INTERIOR
}

\author{
STEWART L. UDALL, Secretary
}

\section{GEOLOGICAL SURVEY}

Thomas B. Nolan, Director

The U.S. Geological Survey Library has cataloged this publication as follows:

\section{Durham, David Leon, 1925-}

Geology of the Jolon and Williams Hill quadrangles, Monterey County, California. Washington, U.S. Govt. Print. Off., 1964.

iv, 27 p. illus., maps (2 col.) diagr., tables. $24 \mathrm{~cm}$. (U.S. Geological Survey. Bulletin 1181-Q)

Contributions to general geology.

Part of illustrative matter fold. in pocket.

Bibliography : p. 26-27.

1. Geology-California-Monterey Co. I. Title: Jolon and Williams Hill quadrangles, Monterey County, California. (Series) 


\section{CONTENTS}

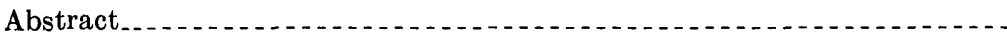

Introduction

Purpose and scope

Location of area..

Previous work

Fieldwork and acknowledgments

Stratigraphy

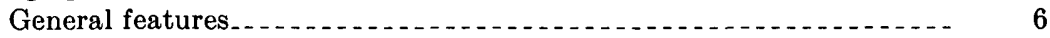

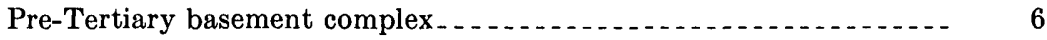

Tertiary(?) System

Paleocene(?) Series.

Unnamed formation

Tertiary System.1. 9

Miocene Series.......... 9

Vaqueros Formation

Monterey Shale

Sandholdt Member.

Pliocene Series.... 14

Unnamed formation............ 14

Tertiary and Quaternary(?) Systems....... 17

Pliocene and Pleistocene(?) Series....... 17

Paso Robles Formation

Quaternary System.

Pleistocene and Recent(?) Series... 19

Older alluvium 19

Recent Series.

Alluvium

Structure.............. 20

General features... 20

Faults............ 22

Folds

Economic geology

Petroleum. 23

Gold

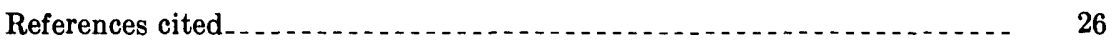




\section{ILLUSTRATIONS}

[Plates are in pocket]

Plate 1. Geologic map and sections of the Jolon quadrangle.

2. Geologic map and section of the Williams Hill quadrangle.

3. Composite generalized stratigraphic section. Page

Figure 1. Index map.

2. Sandstone of Paleocene(?) age

3. Sandstone and mudstone of Paleocene(?) age

4. Thrust fault in Monterey Shale

5. Anticline in Monterey Shale...... 25

TABLES

Page

TARLE 1. Fossils from locality M1455, in the unnamed formation, sec. 36 , T. 23 S., R. 8 E., Williams Hill quadrangle

2. Wells drilled for oil in the Jolon and Williams Hill quadrangles before 1963

3. Fossil localities 


\title{
CONTRIBUTIONS TO GENERAL GEOLOGY
}

\section{GEOLOGY OF THE JOLON AND WILLIAMS HILL QUADRANGLES, MONTEREY COUNTY, CALIFORNIA}

\author{
By David L. Durham
}

\begin{abstract}
The Jolon and Williams Hill $7^{1 / 2}$-minute quadrangles include part of the drainage areas of the San Antonio and Nacimiento Rivers, two major western tributaries of the Salinas River.

Plutonic rocks of the pre-Tertiary basement complex crop out in two small areas near the Nacimiento River, and were reportedly reached in 13 wells drilled northeast of the San Antonio River in the Williams Hill quadrangle.

The oldest sedimentary rocks that crop out in the map area are sandstone, conglomerate, and mudstone beds in the southwestern part of the Jolon quadrangle. They form an unnamed unit that may be thicker than 3,700 feet. Fossil Foraminifera indicate a probable Paleocene age for at least part of the unit.

The Vaqueros Formation crops out southwest of the San Antonio River, where it is in fault contact with older rocks. The exposed part of the formation is no more than 850 feet thick. The Vaqueros is chiefly fine- and medium-grained arkosic sandstone and contains fossil marine mollusks that indicate early Miocene age.

The Monterey Shale conformably overlies the Vaqueros Formation and is the most widespread stratigraphic unit in the map area. The Monterey is chiefly porcelanite and porcelaneous mudstone, but it also contains mudstone, siltstone, sandstone, chert, and dolomitic carbonate rock. Calcareous mudstone and shale beds in the lower part are distinguished as the Sandholdt Member. The Monterey may be thicker than 6,600 feet in the northeastern part of the Williams Hill quadrangle, and the Sandholdt Member is at least 480 feet thick southwest of the San Antonio River. The Monterey is entirely marine. Fossil Foraminifera in the Sandholdt Member indicate the late middle Miocene Luisian Stage of Kleinpell.
\end{abstract}

An unnamed unit that contains arkosic sandstone and interbedded mudstone, diatomaceous mudstone, and porcelaneous rocks conformably overlies the Monterey Shale. This unit is at least 200 feet thick where exposed southwest of the San Antonio River, and it may be much thicker in the subsurface northeast of the river. Fossil marine mollusks in the unit south of the river indicate a Pliocene age.

The Paso Robles Formation, which overlies the unnamed unit with apparent conformity, is chiefly conglomerate, conglomeratic sandstone, and sandstone. 
This formation is less than 200 feet thick southwest of the San Antonio River, but it may be much thicker to the north. The Paso Robles is nonmarine and of Pliocene and probably Pleistocene age.

Older alluvium of Pleistocene and possibly Recent age unconformably overlies the Paso Robles and older formations.

The major structural divisions of the map area are: (a) the structurally high area near the Nacimiento River, where rocks of Paleocene(?) age crop out, (b) the belt of faulted and folded beds of Miocene and Pliocene age near the San Antonio River, (c) the area of low relief and comparatively shallow basement complex on the northeast side of the San Antonio River Valley, and (d) the hills of faulted and folded Monterey Shale in the northeast part of the Williams Hill quadrangle. The major structural features of the area trend northwest.

Seventeen unsuccessful exploratory wells were drilled for oil in the map area before 1963 .

\section{INTRODUCTION}

\section{PURPOSE AND SCOPE}

The Salinas Valley region is favorable for the study of individual formations over a large area because the sedimentary units there are generally widespread and well exposed. The information gathered is useful in interpreting the geologic history and in evaluating the economic mineral potential of the region. U.S. Geological Survey work in the Salinas Valley involves the preparation first, of geologic maps and reports that describe particular quadrangles and, then, of a summary report of regional scope. The first of the reports of local scope described the Reliz Canyon, Thompson Canyon, and San Lucas quadrangles (Durham, 1963), and the second described the Cosio Knob and Espinosa Canyon quadrangles (Durham, 1964). This paper, the third report, describes the Jolon and Williams Hill quadrangles. It includes geologic maps of the Jolon (pl. 1) and Williams Hill (pl. 2) quadrangles, structure sections across them, a list of wells drilled for oil in the map area (table 2), and a list of fossil localities (table 3). The report is preliminary in that some of the interpretations and conclusions are tentative and may be revised as the result of later work.

\section{LOCATION OF AREA}

The Jolon and Williams Hill 71/2-minute quadrangles are west of the Salinas River in southern Monterey County, Calif. (fig. 1). They include part of the drainage areas of the San Antonio and Nacimiento Rivers, both major western tributaries of the Salinas River. More than half of the map area is within the Hunter Liggett Military Reservation.

\section{PREVIOUS WORK}

Whitney (1865) gave the first published description of rocks in the map area. He (p. 148) portrayed the region between the Nacimiento 
and San Antonio Rivers as being made up of high ridges of "bituminous slate," his term for the Monterey Shale, and recognized the general northwest strike of the beds. He (p. 149) noted that the "bituminous slate" is folded and underlain by sandstone that extends southwest to near the Nacimiento River. Whitney (p. 150) also mentioned terraces along the San Antonio River and (p. 158) gold placer operations in the San Antonio River Valley.

Fairbanks (1893, p. 72; 1894, p. 514) remarked on outcrops of granitic rock in the hills between the Nacimiento and San Antonio Rivers and described a syncline in beds of Late Cretaceous age near the Nacimiento River. Later Fairbanks (1900, p. 143) noted the occurrence of "flinty organic shales of the oil-producing formation," that is, of Monterey Shale, near and north of the San Antonio River.

Nutter (1901, p. 335) described the hills between the Nacimiento and Salinas Rivers as being composed almost entirely of sandstone and shale of Miocene age, and he described the valleys of the Nacimiento and San Antonio Rivers as being filled with sands and gravels of Pliocene age.

Hamlin $(1904$, p. 12) reported the local name Sierra de las Piedras for the range of hills between Nacimiento and San Antonio Rivers and represented the ridge as one that diverges from the main Santa Lucia Range to the west. He included charts giving the monthly discharge of the San Antonio River (p. 51) and seasonal rainfall at Jolon (p. 43, 44).

Lawson and others (1908, p. 22) stated that the Nacimiento and San Antonio Rivers occupy well-defined subsequent valleys and explained (p. 19) that the location of the valley of the San Antonio River is probably influenced by the trace of a large fault.

Davis (1912, p. 696) noted the occurrence of placer gold deposits of little economic value in the gravels of the Nacimiento and San Antonio River Valleys.

Vander Leck (1921, p. 87) described the hills northeast of the valley of the San Antonio River as being composed of intensely crushed and folded Monterey Shale, and he mentioned a fault along the northeast side of the valley. He also indicated (p. 86) that the rocks that crop out in the area between the Nacimiento and San Antonio Rivers belong mainly to the Vaqueros Formation.

Hill (1923, p. 325) noted the production of a small quantity of placer gold by Chinese workmen, who had washed gravels of the San Antonio River near Jolon before 1887.

Reed (1925, p. 593) listed two exposures of the contact of the Monterey Shale and the overlying sandstone beds that he assigned to the Santa Margarita Formation. One exposure is along Deer Creek, at 


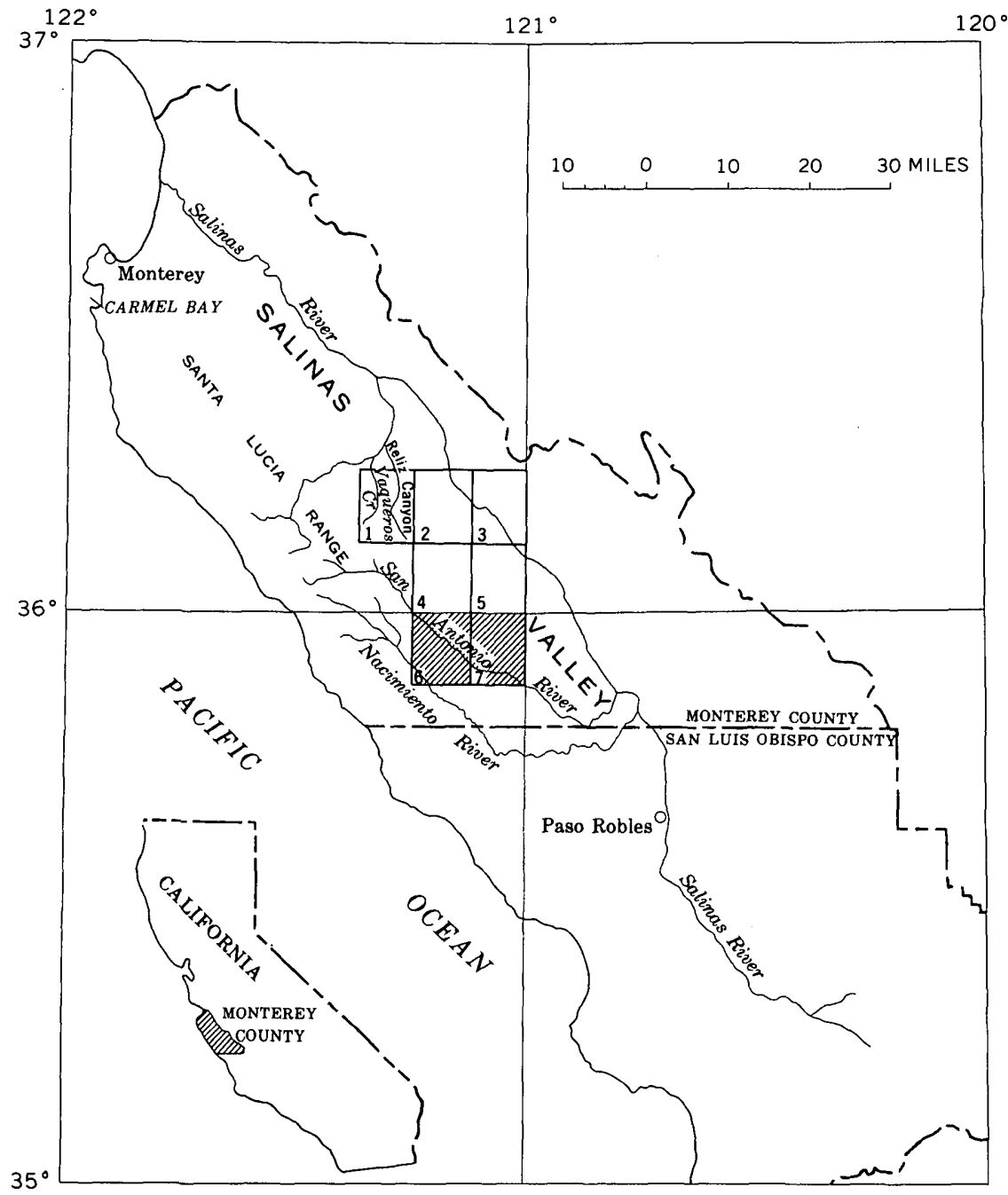

Figure 1.-Index map: (1) Rellz Canyon quadrangle, (2) Thompson Canyon quadrangle, (3) San Lucas quadrangle, (4) Cosio Knob quadrangle, (5) Espinosa Canyon quadrangle, (6) Jolon quadrangle, (7) Williams Hill quadrangle.

or near the south edge of the Williams Hill quadrangle in sec. 3, T. 24 S., R. 8 E., and the second is "along road near crossing of San Antonio [River], sec. 35 [sec. 36 ?], T. 23 S., R. 8 E." Reed (p. 601) described the contact on Deer Creek in detail.

Pike (1926) contrasted the crumpled and overturned beds of the Monterey Shale with the more moderately folded beds of the Vaqueros Formation in the region of the Nacimiento and San Antonio Rivers. $\mathrm{He}$ claimed that the Recent gravels in the San Antonio River Valley. are tilted slightly southwest. 
Wiedey $(1928$, p. 123) described "Turritella montereyana" from a locality in sec. 3, T. 24 S., R. 8 E., near the south edge of the Williams Hill quadrangle.

Clark (1930, p. 801) applied the name San Antonio fault zone to structural features near and parallel to the San Antonio River. He pointed out the marked contrast between the area southwest of the San Antonio River, where a thick sequence of beds of pre-Miocene age overlies the basement complex, and the area northeast of the river, where beds of Miocene age generally lie on the basement complex. He (Clark, 1932, p. 394) attributed a pre-Miocene age to his San Antonio fault zone and remarked that the Cretaceous, Eocene, and Miocene sedimentary rocks southwest of the zone "have the appearance of grading into each other."

Taliaferro (1943a, p. 141) asserted that west of the San Antonio River pronounced angular unconformities occur at the base of the sandstone beds that overlie the Monterey Shale and (p. 147) at the base of the Paso Robles Formation. Taliaferro (1943b, p. 456; 1944, fig. 7) also indicated that strata exposed near the Nacimiento River are of Late Cretaceous age.

Bramlette and Daviess (1944) remarked about the thinness of the Vaqueros Formation in sec. 6, T. 24 S., R. 8 E., near the southeast corner of the Jolon quadrangle, and they described the contact there between the Vaqueros and older rocks as an angular discordance. These authors also showed the general distribution of the Vaqueros in the may area and included structural contours that depict the top of the formation.

Kilkenny (1948, fig. 1) showed a fault, which he labeled San Marcos fault, that trends southeast across the Williams Hill quadrangle near the edge of the hills northeast of the San Antonio River. He (p. 2261) noted that Cretaceous sedimentary rocks occur southwest of this fault, which he described (p. 2264) as a normal fault of Eocene age along which thrusting occurred in late Pliocene time.

\section{FIELDWORR AND ACKNOWLEDGMENTS}

The Jolon quadrangle was mapped in May 1961 and in April and May 1962. The Williams Hill quadrangle was mapped in October, November, and December 1961 and in May 1962. D. C. Wiese assisted in the field in 1962. Field mapping was done on aerial photographs of approximately a $1: 20,000$ scale, and the work was compiled on a topographic base map of a $1: 24,000$ scale.

W. O. Addicott identified collections of mollusks from the map area. Patsy J. Smith identified the Miocene Foraminifera; M. C. Israelsky studied the older Foraminifera. 
Many landowners in the map area kindly allowed access to their property, and the Military Police of Hunter Liggett Military Reservation provided daily information about activity on the firing ranges.

H. H. Haun of Humble Oil and Refining Co. and R. R. Thorup and E. A. Gribi of King City generously provided information on several exploratory wells drilled in the map area.

\section{STRATIGRAPHY}

\section{GENERAL FEATURES}

The pre-Tertiary basement complex crops out in the map area in only two places, but the basement rock reportedly was reached by 13 of the 17 wells drilled for oil there (table 2). Sedimentary rocks that are at least partly of probable Paleocene age crop out in the southwestern part of the Jolon quadrangle. Their stratigraphic relation to younger Teritary units is unclear because these sedimentary rocks are in fault contact with the younger rocks exposed in the map area.

Marine rocks of Miocene and Pliocene age and nonmarine beds of Pliocene and Pleistocene age crop out on both sides of the San Antonio River Valley. Plate 3 shows the sequence, generalized lithology, and approximate thickness of stratigraphic units in the map area.

\section{PRE-TERTIARY BASEMENT COMPLEX}

The basement complex is concealed in the map area except at two places $11 / 2$ miles northeast of the Nacimiento River in secs. 20 and 21 , T. 23 S., R. 7 E., where biotite-rich granitic rocks crop out. These outcrops are shown on the geologic map (pl. 1) as fault-bounded slivers, but this depiction is simply a suggested explanation for the occurrence of these poorly exposed rocks. Similar basement rocks crop out about 3 miles to the north west, outside of the map area. The basement rocks are presumably part of the plutonic mass that Lawson $(1893$, p. 6) named the Santa Lucia Granite and that Trask (1926, p. 134) called the Santa Lucia Quartz Diorite. The age of these rocks may be similar to the age of granodiorite near Carmel Bay that Curtis, Evernden, and Lipson $(1958$, p. 9) determined by the potassium-argon method to be 81.6 million years, or Late Cretaceous in the geological time scale of Holmes (1960).

TERTIARY(?) SYSTEM

PALEOCENE(?) SERIES

UNNAMED FORMATION

Beds that crop out in a triangular area of about 15 square miles in the southwestern part of the Jolon quadrangle are part of a formation 
that is left unnamed. The unit is absent or concealed elsewhere in the map area and is absent or unrecognized in wells drilled north of the San Antonio River. The base of the unnamed formation is concealed in the map area, except possibly in secs. 20 and 21 , T. 23 S., R. 7 E., where the unit could be in depositional contact, rather than in fault contact, with the basement complex. The formation is in fault contact with younger Tertiary rocks exposed in the map area.

\section{LITHOLOGY}

The unnamed formation is chiefly sandstone that is massive (fig. 2), medium and coarse grained, poorly sorted, noncalcareous, and moderate yellowish brown-although locally the sandstone is fine grained, thin bedded (fig. 3), or calcareous. The formation also includes conglomerate, conglomeratic sandstone, and siltstone. Pebbles and cobbles in the conglomerate are rounded and are mainly of plutonic rocks and gneiss, schist, and quartzite similar to rock in the basement complex of the Santa Lucia Range to the northwest. The siltstone is generally massive, noncalcareous, and moderate yellowish brown. A thin section of massive poorly sorted sandstone from sec. 6, T. 24 S., R. 8 E., near the southeast corner of the Jolon quadrangle, contains about 45 percent quartz, 20 percent feldspar, 5 percent biotite, and

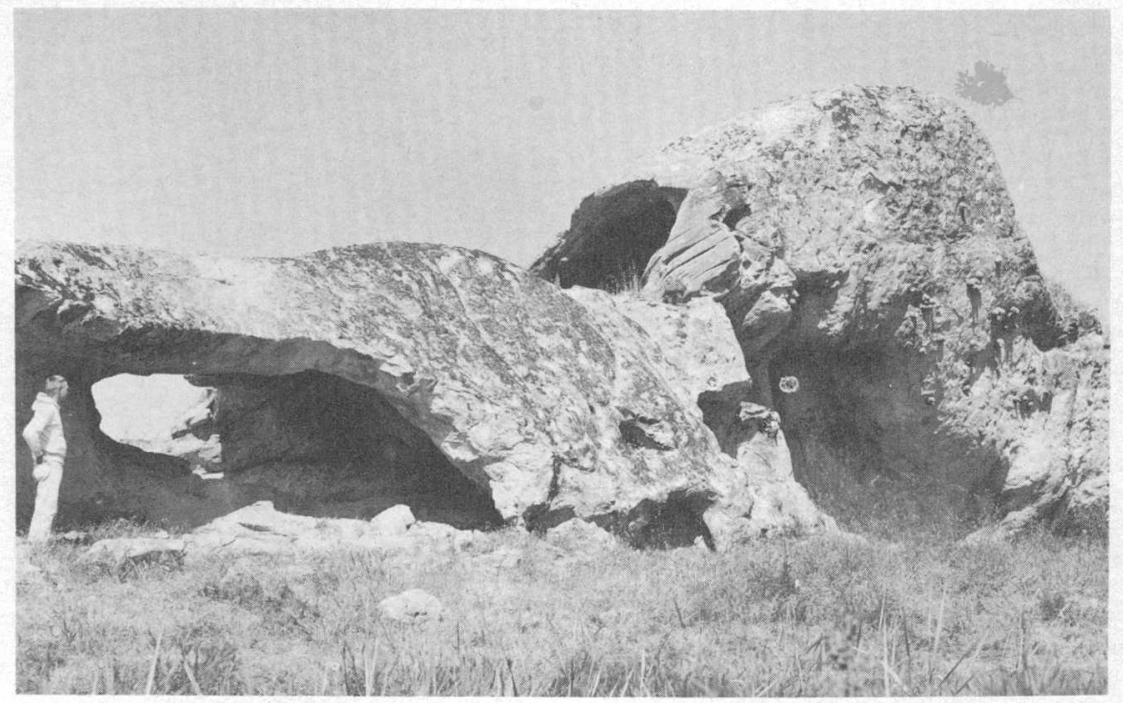

Figure 2.- Sandstone of Paleocene(?) age exposed near the E1/4 cor. sec. 20, T. 23 S., R. $7 \mathrm{E}$. The massiveness and cavernous weathering of the rock are typical of the unnamed formation. 
30 percent matrix of silt or clay. ${ }^{1}$ The sand grains are subangular or subrounded and are mainly 0.3 to $1 \mathrm{~mm}$ in diameter, although some grains and granules are as large as $3.5 \mathrm{~mm}$. A thin section of laminated and cross-laminated sandstone from near the SW cor. sec. 8, T. 23 S., R. 7 E., contains about 40 percent quartz, 25 percent feldspar, and 35 percent biotite. The sand grains are angular and subangular and are generally about $0.1 \mathrm{~mm}$ in diameter. A thin section of thinbedded calcareous sandstone from near the south edge of sec. 33 , T. 23 S., R. 7 E., contains about 15 percent quartz, 30 percent feldspar, 10 percent biotite, and 45 percent calcite matrix. The sand grains are angular to subrounded and 0.2 to $0.6 \mathrm{~mm}$ in diameter.

\section{THICKNESS}

Apparently neither the base nor the top of the unnamed formation crops out in the map area. If the beds north of the Nacimiento River in secs, 28 and 33, T. 23 S., R. 7 E., and sec. 4, T. 24 S., R. 7 E., form a relatively simple monocline, as suggested by scattered exposures, the formation must be at least 3,500 feet thick there. The thickness indicated on structure section $A-A^{\prime}$ (pl. 1) is greater than 3,700 feet.

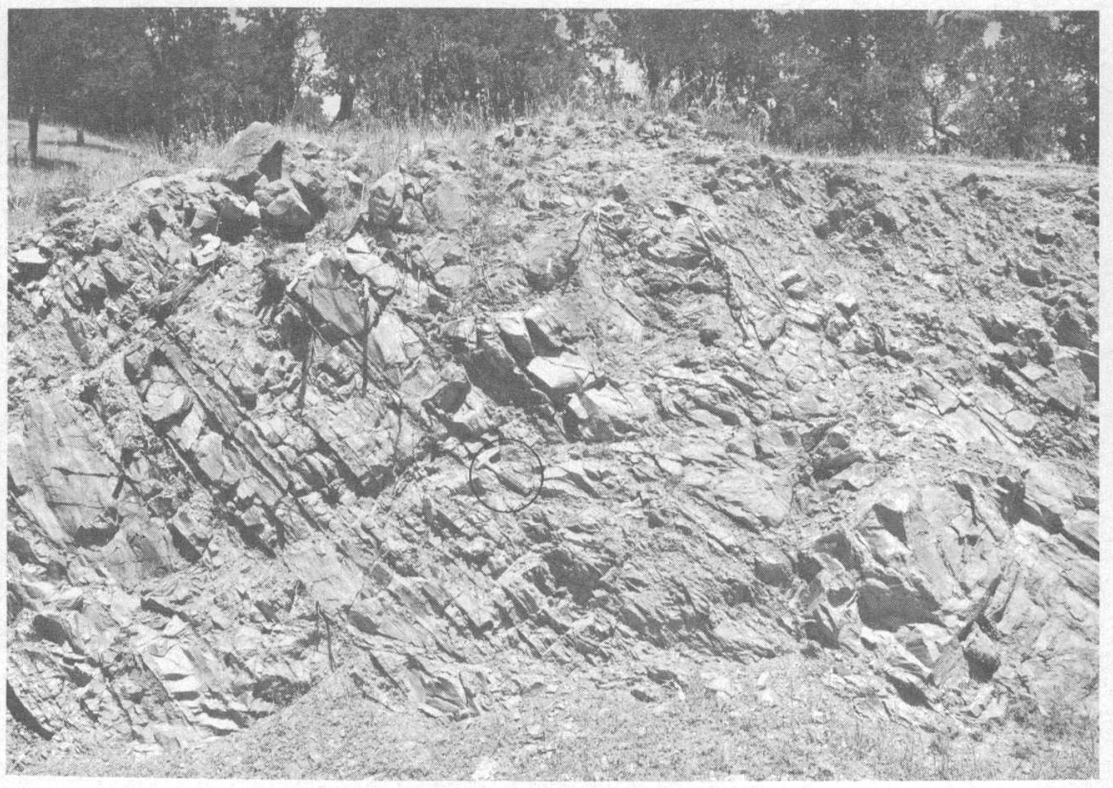

Figure 3.-Interbedded sandstone and mudstone of Paleocene(?) age exposed near the center of the $\mathrm{SW} 1 / 4$ sec. 32 , T. $23 \mathrm{~S}$., R $7 \mathrm{E}$. The pick near the center of the photograph indicates the scale.

\footnotetext{
1 The percentages of constituents in this and other thin sections were determined by the Chayes (1949) point-count method.
} 
The unnamed formation contains few fossils, and because it is in fault contact with other rocks in the map area, its stratigraphic position is doubtful. Fossil Foraminifera from mudstone at locality Mf722, southwest of the Nacimiento River in the Jolon quadrangle, indicate a probable Paleocene age for at least part of the formation (M. C. Israelsky, oral commun., 1963). Sandstone and mudstone beds that are similar to those in the unnamed formation crop out about 9 miles northwest of the Jolon quadrangle. There, at fossil locality M1677, 725 feet south and 300 feet east of the NW cor. sec. 36, T. 21 S., R. 5 E., in the Cone Peak 71/2-minute quadrangle, sandstone beds contain Turritella pachecoensis and are thus considered to be of Paleocene age (W. O. Addicott, written commun., 1963). The fossil Foraminifera indicate that the unit is at least partly of marine origin.

\section{TERTIARY SYSTEM}

\section{MIOCENE SERIES}

\section{VAQUEROS FORMATION}

Hamlin (1904) gave the name Vaquero Sandstone to strata exposed along Vaqueros Creek, about 13 miles northwest of the Jolon quadrangle. Others (for example, English, 1918) later applied the modified term Vaqueros Sandstone to the unit, but the name Vaqueros Formation, which lacks a lithologic characterization, best reflects the diversity of rocks in the formation at its type area (Durham, 1963).

The Vaqueros Formation crops out southwest of the San Antonio River in a belt as wide as one-half mile that trends northwest across the Jolon quadrangle. The exposed Vaqueros is in fault contact with older rocks. Sandstone that overlies the basement complex in the subsurface northeast of the San Antonio River is probably at least partly Vaqueros (structure section $A-A^{\prime}$, pl. 1).

\section{LITHOLOGY}

The Vaqueros Formation in the map area is chiefly sandstone that is fine or medium grained, very light gray or yellowish gray, and calcareous, but locally it includes sandstone that is coarse grained and pebbly. The formation commonly consists of units of well-indurated sandstone that alternate with units of friable sandstone. The wellindurated sandstone is cemented with calcite, and the friable sandstone has a partly calcareous or silty matrix. Irregular or ellipsoidal calcareous concretions as long as 2 or 3 feet occur in the Vaqueros at some localities, and calcite commonly fills joints in the sandstone. The 
thickness of individual sandstone beds is generally 1 to 3 feet, but in some places it is less than 1 inch. Mollusk shells or shell fragments are abundant in some beds. Three thin sections of random samples of well-cemented fine-grained sandy rock contain 50 to 60 percent calcite matrix, 20 to 25 percent quartz, 20 to 25 percent feldspar, 5 percent biotite, and less than 2 percent rock fragments and dark mineral grains. The sand grains are angular and subangular. Their size ranges from 0.06 to $0.35 \mathrm{~mm}$ across but is generally 0.1 to $0.2 \mathrm{~mm}$. A thin section from a bed of massive, poorly sorted pebbly sandstone at fossil locality M1453, near the NW cor. sec. 36, T. 23 S., R. 7 E., contains about 40 percent calcite matrix, 20 percent shell fragments, 10 percent arkosic sand, 20 percent granules, and 10 percent pebbles. The pebbles and granules are generally rounded, and the sand grains, which are mostly 0.3 to $0.6 \mathrm{~mm}$ across, are angular.

Siltstone, in poorly exposed units that may be as thick as several tens of feet, is interbedded with the sandstone in some places. It is generally moderate yellowish brown, massive, and noncalcareous and has a hackly fracture.

THICKNESS

The base of the Vaqueros Formation is concealed in the map area. The thickness of the part of the Vaqueros exposed along the line of structure section $A-A^{\prime}$ (pl. 1), in sec. 22, T. 23 S., R. 7 E., is about 850 feet, and the total thickness of the formation may be much greater. Sandy beds that are questionably assigned to the Vaqueros were penetrated for about 2,600 feet in the Humble Oil and Refining Meta E. Oberg et al. 1, in sec. 19, T. 22 S., R. 8 E., near the north edge of the Jolon quadrangle (structure section $A-A^{\prime}$, pl. 1).

\section{AGE AND CONDITIONS OF DEPOSITION}

Specimens of Lyropecten magnolia from locality M1453, near the NW cor. sec. 36, T. 23 S., R. 7 E., and from locality M1454, in sec. 6, T. 24 S., R. 8 E., are the only identifiable fossils collected from the Vaqueros Formation in the map area, but they are indicative of early Miocene age, in terms of the California megafossil chronology (W. O. Addicott, written commun., 1962). Fossils in the Vaqueros indicate that the formation is at least partly marine, and their distribution suggests that the part of the unit exposed in the Jolon quadrangle probably is entirely marine.

\section{MONTEREY SHALE}

Blake (1855) named the Monterey Shale for exposures near the town of Monterey, about 55 miles northwest of the Jolon quadrangle. The lower part of the Monterey Shale is distinguished in the map area 
as the Sandholdt Member (Durham, 1963). The Monterey Shale crops out mainly northeast of the San Antonio River Valley in the Williams Hill quadrangle and southwest of the valley in a belt about 2 miles wide that trends northwest across the map area. Patches of Monterey that are surrounded by older alluvium or alluvium crop out at several places near the river.

The Monterey Shale conformably overlies the Vaqueros Formation. The lower contact of the Sandholdt Member of the Monterey is at the base of the stratigraphically lowest beds of calcareous mudstone or shale that overlie the dominantly sandy Vaqueros. The base is best exposed near the NE cor. sec. 7, T. 23 S., R. 7 E., and in the northern part of sec. 36, T. 23 S., R. 7 E.

\section{SANDHOLDT MEMBER}

The dominantly calcareous beds in the lower part of the Monterey Shale constitute the Sandholdt Member. The type area of the member is in Reliz Canyon, about 13 miles north of the Jolon quadrangle (Durham, 1963). The Sandholdt crops out in fault blocks near the west edge of the Jolon quadrangle and along the southwest margin of the belt of Monterey Shale that trends diagonally across the quadrangle. The member is mainly calcareous mudstone and shale, but in some places it contains conspicuous amounts of siltstone, sandstone, porcelaneous rocks, chert, and dolomitic carbonate rock. The dominance of calcareous rocks in the member is its chief lithologic distinction. The descriptions of the rocks in the member are included with the lithologic description of the whole formation.

The upper contact of the Sandholdt Member is conformable and also gradational, for siliceous rocks characteristic of the upper part of the Monterey occur in the Sandholdt as well. The upper contact, which may not be at the same stratigraphic horizon throughout the may area, is best exposed near the north edge of sec. 36, T. 23 S., R. $7 \mathrm{E}$.

LITHOLOGY

\section{Porcelaneous rocks}

Porcelanite and porcelaneous mudstone constitute an estimated three-fourths of the Monterey Shale exclusive of the Sandholdt Member. Porcelanite is a siliceous rock that resembles unglazed porcelain. $\boldsymbol{X}$-ray analysis of the rock indicates that the silica is mainly cristobalite, quartz, and opal (R. A. Gulbrandsen, oral commun., 1962). Porcelanite grades into porcelaneous mudstone and into mudstone by an increase in the ratio of clastic material to silica matrix. Some beds contain all three types of rock in irregular and gradational layers or lenses.

Beds of porcelanite and porcelaneous mudstone are generally 1 to 6 inches thick, but locally the rock may be either thinner or thicker 
bedded. The bedding surfaces are most commonly nearly planar, but some are conspicuously irregular. Some porcelaneous rocks are laminated but lack fissility. They are chiefly pinkish gray or very pale orange but have a wide range of color that is mainly related to weathering. Porcelaneous mudstone commonly contains fish scales and molds of Foraminifera.

\section{Clastio rocks}

Mudstone is second in abundance to porcelaneous rocks in the Monterey Shale. Mudstone in the Sandholdt Member is mainly calcareous and friable, and mudstone in the upper part of the Monterey is noncalcareous and well cemented. The mudstone is ordinarily shaly, in beds 1 to 6 inches thick, but at some localities it is in beds 2 or more feet thick. Most commonly, both the calcareous and noncalcareous mudstones are very pale orange, but they have a wide color range that is related to weathering. The calcareous mudstone contains abundant fossil Foraminifera at some localities, and the noncalcareous rock contains fish scales, fossil diatoms, and molds of Foraminifera.

A thin section of laminated noncalcareeus mudstone from sec. 30 , T. 22 S., R. 7 E., in the Jolon quadrangle, contains about 7 percent angular sand grains that range in size from 0.06 to $0.2 \mathrm{~mm}$. A thin section of platy mudstone from sec. 29 , T. 22 S., R. 9 E., in the Williams Hill quadrangle, contains grains that are mainly 0.04 to 0.06 $\mathrm{mm}$ across, although a few are as large as $0.25 \mathrm{~mm}$.

The lower part of the Sandholdt Member contains interbedded siltstone and sandstone. The siltstone is calcareous and commonly pale yellowish brown or very pale orange. The thickness of the siltstone beds is generally less than 2 inches, but at some localities it is as much as 2 feet. The sandstone is fine grained, calcareous, and pale yellowish orange. The thickness of the sandstone beds is commonly as much as 2 or 3 feet, but at some places it is less than an inch.

\section{Carbonate beds and concretions}

Dolomitic carbonate beds and concretions are estimated to constitute less than 5 percent of the Monterey Shale, but they are conspicuous because they are generally more resistant to weathering than are the enclosing beds. Dolomitic carbonate beds occur in both the Sandholdt Member and the upper part of the Monterey. Their thickness is commonly 6 to 12 inches, but at some localities it is 2 feet or more. The exposed rock is ordinarily very pale orange, but it has a wide color range that is mainly the result of weathering. X-ray analysis of similar rock from the Monterey in Reliz Canyon suggests that the carbonate is ferrous dolomite (R. A. Gulbrandsen, oral commun., 1962). Calcite commonly fills joints in the carbonate beds. The 
Monterey also contains ellipsoidal concretions of dolomitic carbonate rock that are as thick as 2 feet and as long as 4 feet.

\section{Chert}

Chert forms a small but conspicuous part of the Monterey Shale. It occurs both in the Sandholdt Member and in the upper part of the Monterey and is apparently more common south of than north of the San Antonio River. The chert is generally light olive gray, brownish gray, or brownish black and forms irregular beds 1 to 12 inches thick. Chert beds are associated with both porcelaneous and calcareous rocks.

\section{THICKNESS}

A completely exposed and unfaulted section of the Monterey Shale is lacking in the map area. The Sandholdt Member is about 480 feet thick, as measured on the geologic map where the structural relations are simple near the NW cor. sec. 36, T. 23 S., R. 7 E., in the Jolon quadrangle, and about 525 feet thick, as measured on structure section $B-B^{\prime}$ (pl. 2). The Sandholdt is apparently more than 900 feet thick where shown on structure section $A-A^{\prime}$ (pl. 1), but structural complications may cause the unit to appear too thick there. The thickness of the Monterey Shale northeast of the San Antonio River has a wide range. The General Petroleum Hotchkiss 35-29, in sec. 29; T. 22 S., R. 9 E., near the northeast corner of the Williams Hill quadrangle, was reportedly drilled in Monterey Shale to the depth of 6,259 feet (structure section $B^{\prime}-B^{\prime \prime}, \mathrm{pl} .2$ ), but some wells in the southeast quarter of the quadrangle were drilled through little or no Monterey Shale before reaching the basement complex. The thickness of the Monterey south of the San Antonio River is indicated on structure section $B^{\prime}-B^{\prime \prime}$ (pl. 2) to be greater than 2,700 feet, and the thickness of the Monterey north of the river is indicated on the same structure section to be greater than 6,600 feet.

AGE AND CONDITIONS OF DEPOSITION

The base of the Sandholdt Member of the Monterey Shale in sec. 36 , T. 23 S., R. 7 E., is about 200 feet stratigraphically above fossil locality M1453, which contains Lyropecten magnolia, an indicator of early Miocene age. At fossil locality Mf628, in sec. 22, T. 23 S., R. 7 E., the Sandholdt Member contains the following Foraminifera that indicate the late middle Miocene Luisian Stage of Kleinpell (Patsy B. Smith, written commun., 1962) :

\footnotetext{
Epistominella relizensis (Kleinpell)

Uvigerina modeloensis Cushman and Kleinpell

Siphogenerina collomi Cushman

S. reedi Cushman

Globigerina hexagona Natland
} 
Beds in the Sandholdt about 50 feet stratigraphically below fossil locality Mf628 contain the following Foraminifera that indicate a middle Miocene age and probably the Luisian Stage (Patsy B. Smith, written commun., 1962) :

\section{Baggina robusta Kleinpell \\ Anomalina salinasensis Kleinpell \\ Cassidulina crassa d'Orbigny \\ Pullenia miocenica Kleinpell \\ Siphogenerina branneri (Bagg) \\ Globigerina bulloides d'Orbigny \\ G. hexagona Natland}

Fossils are poorly preserved or absent in the upper part of the Monterey Shale. Fossil mollusks from beds that conformably overlie the Monterey at locality M1455, south of the San Antonio River in the Williams Hill quadrangle near the $\mathrm{W}^{1} / 4$ cor. sec. 36 , T. 23 S., R. 8 E., are of Pliocene age (W. O. Addicott, oral commun., 1964). Thus, by its fossil content and stratigraphic position, the Monterey Shale in the map area is at least partly middle Miocene and partly late Miocene in age.

Foraminifera, fish scales, and molds of clam shells in the Monterey Shale indicate the marine origin of the formation.

\section{PLIOCENE SERIES}

UNAAMED FORMATION

Beds of sandstone and interjacent beds of mudstone, diatomaceous mudstone, and porcelaneous rocks that overlie the Monterey Shale in the map area are left unnamed because of uncertainty as to their relation to beds elsewhere in the Salinas Valley that were referred to the Santa Margarita Formation by Fairbanks (1904), to the Santa Margarita Formation and the Jacalitos and Etchegoin Formations by English $(1918$, p. 229, 231), to the Poncho Rico Formation by Reed (1925), and to the King City Formation by Clark (1940). They are tentatively correlated with similar unnamed beds in the quadrangles to the north (Durham, 1963, 1964).

Sandstone and diatomaceous mudstone beds that are assigned to the unnamed formation crop out in the Jolon quadrangle in a structurally complex northwest-trending belt about one-quarter mile wide that lies near the edge of the hills northeast of the San Antonio River. The formation crops out in the Williams. Hill quadrangle on both sides of the river, and beds questionably assigned to the unit crop out in several small areas near the margin of the hills in the northern part of the quadrangle. Several wells drilled near and southeast of Lockwood penetrated the unit.

The unnamed formation conformably overlies the Monterey Shale. The contact, which is at the base of the stratigraphically lowest sand- 
stone beds that overlie the Monterey, is gradational, for rocks characteristic of the Monterey also occur in the unnamed formation. The contact, which is best seen in sec. 4, T. 24 S., R. 8 E., near the south edge of the Williams Hill quadrangle, may not be at the same stratigraphic horizon throughout the map area.

\section{Sandstone}

LITHOLOGY

Sandstone of the unnamed formation ranges from very fine grained to coarse grained and pebbly. It commonly lacks well-defined bedding, but where beds are apparent, they are generally 6 to 24 inches thick. Some of the sandstone is well cemented with calcite; some is well indurated but lacks calcareous cement; and some is almost unconsolidated, like that at Quail Top, in sec. 33, T. 23 S., R. 8 E. Rounded granules and small pebbles of volcanic and basement rocks are common in sandstone beds near the top of the formation south of the San Antonio River. The weathered rock is generally very pale orange or pinkish gray. Fossils or fragments of fossils-including mollusks, echinoids, diatoms, and Foraminifera-are abundant in some beds.

A thin section of massive sandy rock from beds which are questionably assigned to the unnamed formation in sec. 28 , T. 22 S., R. 8 E., north of the San Antonio River in the Williams Hill quadrangle, contains about 15 percent quartz, 20 percent feldspar, 5 percent rock fragments, 10 percent Foraminifera tests and fragments of fossil echinoids, and 50 percent calcite matrix. The sand grains are angular to rounded and are generally 0.3 to $0.6 \mathrm{~mm}$ across, although some grains and granules are as large as $2.5 \mathrm{~mm}$. A thin section of similar rock from sec. 33, T. 23 S., R. 8 E., at Nelson Flat, south of the San Antonio River in the Williams Hill quadrangle, contains about 5 percent quartz, 10 percent feldspar, 3 percent rock fragments, 20 percent mollusk shell fragments, and 62 percent calcite matrix. The grains are subangular or subrounded and are mostly 0.3 to $0.6 \mathrm{~mm}$ in diameter, but they range from 0.15 to $1.6 \mathrm{~mm}$. A thin section of noncalcareous sandstone from a bed, questionably assigned to the unnamed formation, that overlies diatomaceous mudstone beds west of the mouth of Wildcat Canyon in sec. 2, T. 23 S., R. 8 E., in the Williams Hill quadrangle, contains about 25 percent quartz, 25 percent feldspar, 10 percent rock fragments (chiefly chert), and 40 percent silt and clay matrix. The sand grains are angular to rounded and are generally 0.1 to $0.6 \mathrm{~mm}$ in diameter, although some are as large as $2 \mathrm{~mm}$. The sandstone contains molds and casts of clams, and includes scattered rounded pebbles of chert that have sand-filled holes formed by boring clams before the clasts were incorporated into the rock. Two thin sections of very fine grained pinkish-gray noncalcareous sandstone from secs. 33 and $35, \mathrm{~T}$. 
23 S., R. 8 E., south of the San Antonio River in the Williams Hill quadrangle, contain 40 to 50 percent sand grains and 50 to 60 percent silt and clay matrix. The sand grains are generally angular and 0.06 to $0.2 \mathrm{~mm}$ across, although a few scattered grains are as large as 0.75 $\mathrm{mm}$. The rock is massive and well indurated and is associated with beds of porcelanite and diatomaceous mudstone.

\section{Mudstone}

Mudstone in the unnamed formation is pinkish gray or white, noncalcareous, and generally massive and moderately friable. Fossil diatoms are abundant in some beds. A thin section of pinkish-gray diatomaceous mudstone from a unit of interbedded mudstone and very fine grained sandstone near the base of the unnamed formation at the N1/4 cor. sec. 4, T. 24 S., R. 8 E., south of the San Antonio River in the Williams Hill quadrangle, contains about 12 percent sand grains and 88 percent silt and clay matrix. The sand grains, which are randomly scattered in the rock, are angular and generally about $0.09 \mathrm{~mm}$ in longest dimension, although they range from 0.06 to $0.18 \mathrm{~mm}$. A thin section of friable mudstone from vertical beds in the SW1/4 sec. $21, T$. 23 S., R. 9 E., north of the San Antonio River in the Williams Hill quadrangle, contains about 5 percent sand grains and 95 percent silt and clay matrix. The sand grains are angular and 0.09 to $0.14 \mathrm{~mm}$ in diameter. The rock is fissile, in beds about 1 inch thick, and contains biotite flakes and fossil Foraminifera.

\section{Porcelaneous rocks}

Porcelaneous rocks in the unnamed formation are similar to those in the Monterey Shale. They occur mainly in the lower part of the unit.

\section{THICKNESS}

The unnamed formation is apparently at least 200 feet thick where exposed southwest of the San Antonio River along the line of structure section $B^{\prime}-B^{\prime \prime}$ (pl. 2). The formation is about 160 feet thick $11 / 2$ miles to the southeast, as measured on the geologic map, and is even thinner 1 to 3 miles farther east. It may be much thicker northeast of the San Antonio River in the Jolon quadrangle, where the Humble Oil and Refining Meta E. Oberg et al. 1 was drilled for 1,200 feet through beds questionably assigned to the unnamed formation (structure section $A-A^{\prime}$, pl. 1).

\section{AGE AND CONDITIONG OF DEPOSITION}

Mollusk shells are abundant in some beds of the unnamed formation, but they are generally fragmentary or poorly preserved. Table 1 lists the fauna from fossil locality M1455, near the W1/4 cor. sec. 
36, T. 23 S., R. 8 E., that indicates a Pliocene age (W. O. Addicott, oral commun., 1964). By its stratigraphic position and fossil content, the formation is considered Pliocene in age.

The fossiliferous beds in the unnamed formation are evidence for the marine origin of at least part, and presumably all, of the unit.

TABLE 1.-Fossils from locality M1455, in the unnamed formation, sec. 36 , T. 23 S., R. 8 E., Williams Hill quadrangle

[Identified by W. O. Addicott]

Gastropods :

Bittium sp.

Calyptraea sp.

Cancellaria cf. C. fernandoensis Arnold

Crepidula adunca Sowerby

Nassarius cf. N. iniquus (Stewart)

Nassarius sp.

Neverita sp.

Olivella sp.

Scaphander aff. S. jugularis (Conrad) of Anderson, 1905

Turritella cooperi Conrad

Pelecypods :

Anadara cf. A. trilineata (Conrad)

Clinocardium? sp.

Cryptomya californica Conrad

Florimetis biangulata (Oarpenter)

Lucina excavata Carpenter

Lucinisca $\mathbf{n}$. sp.

Lyropecten? aff. L. cerrosensis (Gabb)

Macoma nasuta (Conrad)

Mytilus cf. M. coalingensis Arnold

Protothaca staminea (Conrad)

Protothaca tenerrima (Carpenter)

Solen cf. S. perrini Clark

Spisula sp.

\section{TERTIARY AND QUATERNARY (P) SYSTEMS}

\section{PLIOCENE AND PLEISTOCENE(?) SERIES}

PABO ROBLES FORMATION

Fairbanks (1898) gave the name Paso Robles Formation to nonmarine beds exposed near the town of Paso Robles, about 25 miles southeast of the Williams Hill quadrangle. The formation crops out in the hills north of the San Antonio River in the Jolon quadrangle and in several areas near the river in the Williams Hill quadrangle.

The Paso Robles Formation overlies the unnamed formation with apparent conformity at most places in the map area, but beds north of the San Antonio River questionably assigned to the Paso Robles (pl. 2) unconformably overlie both the Monterey Shale and the unnamed formation. The contact is at the base of the stratigraphi- 
cally lowest unfossiliferous conglomerate bed that overlies the finer grained rocks of the unnamed formation, or, locally, of the Monterey Shale. The contact with the unnamed formation is generally gradational, and the conglomerate at the base of the Paso Robles has a matrix of friable sandstone similar to sandstone in the underlying beds of the unnamed formation. The contact is irregular near the center of the SW1/4 sec. 34, T. 23 S., R. 8 E., where part of the unnamed formation was apparently eroded prior to deposition of the Paso Robles.

\section{LITHOLOGY}

The Paso Robles Formation in the map area is chiefly conglomerate, conglomeratic sandstone, and sandstone. The larger clasts are generally rounded pebbles of porcelaneous rock and chert that are $1 / 2$ to 2 inches long. Locally, the conglomerate contains cobbles, and south of the San Antonio River, it commonly includes clasts of volcanic and basement rocks in addition to those of porcelaneous rocks and chert. The conglomerate generally has a matrix of friable poorly sorted arkosic sandstone. Conglomerate that is exposed in the Williams Hill quadrangle in sec. 21 , T. 23 S., R. 9 E., north of the San Antonio River, and in the west half of sec. 36, T. 23 S., R. 8 E., south of the river, is questionably assigned to the Paso Robles. It consists of pebbles of porcelaneous rocks and chert so firmly cemented by silica that the rock breaks across, rather than around, the larger clasts. This well-cemented rock is identical with conglomerate at the base of the Paso Robles Formation in the Thompson Canyon and San Lucas quadrangles (Durham, 1963) 10 to 17 miles north of the map area.

Sandstone in the Paso Robles Formation is arkosic and generally massive, friable, and poorly sorted. It is commonly interbedded with, or grades into, conglomerate. Locally, sandstone is associated with beds of noncalcareous mudstone 1 to 2 feet thick.

The beds near Tule Canyon in the Williams Hill quadrangle that are questionably assigned to the Paso Robles Formation (pl. 2) include resistant beds of limestone. These limestone beds cap flat-topped ridges just north of the San Antonio River west of Tule Canyon.

THICKNESA

The Paso Robles Formation exposed south of the San Antonio River is no thicker than 200 feet but north of the river, where good exposures are lacking, it may be several hundred feet thick.

\section{AGE AND CONDITIONS OF DEPOSITION}

The Paso Robles Formation lacks indigenous fossils in the map area. This formation overlies beds that contain fossils of Pliocene age and unconformably underlies older alluvium and alluvium of 
Pleistocene and Recent age. The Paso Robles is thus limited in age to the Pliocene and Pleistocene.

The Paso Robles Formation is considered nonmarine because it lacks marine fossils and generally resembles the overlying older alluvium. The base of the Paso Robles presumably represents the beginning of nonmarine deposition following withdrawal of the Tertiary sea from the map area.

\section{QUATERNARY SYSTEM}

\section{PLEISTOCENE AND RECENT(?) SERIES}

\section{OLDER aLLUVIUM}

Older alluvium covers the area of low relief near the San Antonio River and forms a series of coalescing alluvial fans that border the hills in the northeast part of the Williams Hill quadrangle. It also occurs in the valleys of manyi of the larger tributaries to the San Antonio and Nacimiento Rivers, where it is generally incised by modern streams.

Patches of older alluvium on the flanks of Williams Hill and on the hills southwest of the San Antonio River are remnants of formerly more extensive fluviatile deposits unrelated to the present streams. Only the larger remnants are shown on the geologic maps (pls. 1 and 2). Scattered cobbles and small boulders of basement rock on some of the high ridges of Monterey Shale south of the river are probably the local residuum of similar deposits.

Older alluvium may cap some of the hills mapped as the Paso Robles Formation in the Jolon quadrangle, but the resemblance of older alluvium to the Paso Robles generally makes the distinction there impractical.

The older alluvium lies unconformably on the Paso Robles and older formations and is flat lying or has a small initial dip. It is apparently unaffected by faults that displace the Paso Robles and older formations.

The older alluvium commonly consists of poorly indurated gravel, sand, and silt, but in some places it is well cemented. Pebbles and cobbles in the older alluvium are generally of porcelaneous rocks similar to rock in the Monterey Shale, but the older alluvium in patches near China Gulch, southwest of the San Antonio River, is unusual because it contains clasts of volcanic rocks and red and green chert that were apparently derived from the Franciscan terrane of the Santa Lucia Range southwest of the map area.

The older alluvium lies unconformably on the Paso Robles Formation, and because of this stratigraphic position, it is considered of Pleistocene and possibly Recent age. This alluvium is of fluviatile origin. 
RECENT SERIES

ALIUVIUM

The beds of the San Antonio and Nacimiento Rivers and their tributaries contain sand and gravel. Two hundred pebbles and small cobbles counted at two localities along the San Antonio River were about 80 percent rocks from the basement complex, 15 percent porcelaneous rocks and chert, and 5 percent sandstone. Two hundred clasts counted at a gravel bar along the Nacimiento River were about 80 percent rocks from the basement complex, 20 percent sandstone, and 5 percent volcanic rocks.

\section{STRUCTURE}

\section{GENERAL FEATURES}

The major structural divisions of the map area, in order from southwest to northeast, are: (a) the structurally high area in the southwest corner of the Jolon quadrangle where beds of Paleocene(?) age crop out, (b) the northwest-trending belt of faulted and folded rocks of Miocene and Pliocene age near the San Antonio River, (c) the area of low relief and a comparatively shallow basement complex that extends from the northeast part of the Jolon quadrangle southeast across the center of the Williams Hill quadrangle, and (d) the hills of faulted and folded Monterey Shale in the northeast part of the Williams Hill quadrangle. The major faults in the map area trend northwest, but cross faults that trend north to northeast are common. The axes of the larger folds generally trend northwest.

The structurally high area in the southwest corner of the Jolon quadrangle, where beds of Paleocene(?) age crop out, is bounded on the northeast by faults. The beds northeast of the Nacimiento River generally dip $10^{\circ}-40^{\circ} \mathrm{SW}$., except where they are locally disrupted by faults or broad folds. The beds southwest of the river generally dip more steeply, form northwest-trending folds, and may be affected by one or more northwest-trending faults.

A belt about 4 miles wide that contains rocks of Miocene and Pliocene age extends from the northwest corner of the Jolon quadrangle southeast into the southern part of the Williams Hill quadrangle. The San Antonio River follows a median course along the length of the belt. Southwest of the river in the Jolon quadrangle, faulted and tightly folded beds of the Vaqueros Formation and Monterey Shale form a range of high hills. On both sides of the river in the Williams Hill quadrangle, large faults are apparently scarce, and the Monterey Shale and overlying beds of Tertiary age form broad folds. Northeast of the river, rocks of Tertiary age are generally concealed beneath older alluvium. The northeast border of the belt may be the system 
of faults that is exposed in the hills northwest of Jolon. This fault system presumably continues southeast beneath the older alluvium and may lie concealed beneath strata questionably assigned to the Paso Robles Formation near the patch of Monterey Shale that is exposed along Tule Canyon in and near sec. 22, T. 23 S., R. 8 E.

The area of low relief that extends diagonally across the map area from north of Jolon to the southeast corner of the Williams Hill quadrangle is apparently structurally different from the areas to the southwest and northeast. The Paso Robles Formation crops out at the northwest end of the area, but elsewhere the Paso Robles and older formations are concealed by older alluvium. Several wells that were drilled for oil near the southeast end of the area in secs. 18, 19, and 33, T. 23 S., R. 9 E., penetrated an abbreviated sequence of beds of Tertiary age and reached the pre-Tertiary basement complex at depths between 200 and 600 feet below sea level (table 2). Information from wells drilled to the northwest suggests that the Monterey Shale is thinner, and the post-Monterey marine unit is thicker than they are near the San Antonio River (structure section $A-A^{\prime}$, pl. 1). Rocks of middle Miocene age are reportedly absent in some of the wells. The northeast boundary of this structural subdivision is apparently a system of faults concealed by older alluvium near the edge of the hills in the northeast part of the Williams Hill quadrangle, although the northwest-trending fault exposed in sec. 20 , T. 23 S., R. 9 E., may belong to the system. This system of faults may be the southeast extension of the fault zone that similarly forms the southwest border of hills in the Cosio Knob quadrangle (Durham, 1964).

The hills in the northeast corner of the Williams Hill quadrangle are characterized by a thick sequence of Monterey Shale beds that are faulted and folded. The major faults trend northwest, but east- to northeast-trending cross faults are common. The General Petroleum Wright-Texas 25-5, between the traces of two large northwesttrending faults in sec. 5, T. 23 S., R. 9 E., reportedly bottomed in the pre-Tertiary basement complex at a depth of 2,587 feet. The General Petroleum Hotchkiss 35-29, drilled about 2 miles to the north across a large fault, reportedly failed to reach the basement complex at its total depth of 6,259 feet.

Structure section $A-A^{\prime}, B-B^{\prime}$, and $B^{\prime}-B^{\prime \prime}$ (pls. 1 and 2) illustrate the near-surface structure of the map area, mainly as extrapolated from surface data. The faults on the sections are arbitrarily shown as vertical, but information concerning their dip is generally lacking. The folds exposed at the surface are assumed to extend to the base of the sections as parallel folds. 


\section{FAULTS}

The location or approximate location of faults that separate rocks of unlike lithologic character in the map area is generally apparent, but the location or even the existence of faults that are confined to a single lithologic unit such as the Monterey Shale is commonly in doubt. Small faults in the Monterey, like the one shown in figure 4, can only rarely be traced for any distance, but they are of interest as examples of how the Monterey is deformed. Faults located with certainty are indicated on the geologic maps by a solid line. Those located only approximately, generally because they are in areas of poor exposure, are indicated by a dashed line. Faults whose location and existence are inferred from indirect evidence are indicated by a dashed line with queries. The inferred faults are generally shown to separate areas of unlike structure or to link a series of anomalous structural features. Some inferred faults represent extensions of known faults.

Some faults in the map area are of particular interest. The inferred fault that is shown to trend northwest from sec. 27 to sec. 17, T. 23 S., R. 7 E., $11 / 2$ miles northeast of the Nacimiento River, is based on outcrops of pre-Tertiary basement complex that are interpreted on the map as slivers of basement complex uplifted along the fault.

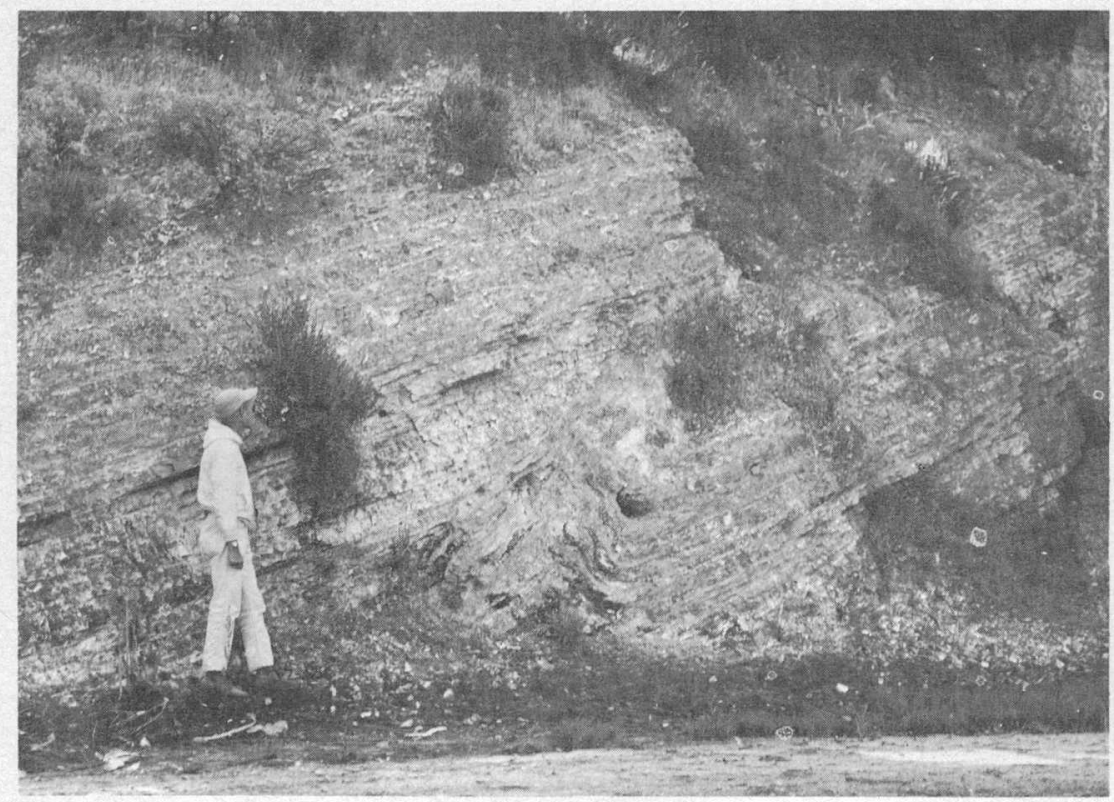

Fradre 4.- Small thrust fault in Monterey Shale, exposed in the bank of the San Antonio River near the $\mathrm{N} 1 / 4$ cor. sec. 34 , T. 23 S., R. $8 \mathrm{E}$. 
The fault that separates the unnamed formation of Paleocene(?) age from younger beds in the southwestern part of the Jolon quadrangle can be located approximately by the discordance of structure across it, even though the fault separates rocks of similar lithologic character but different age and is generally concealed by soil or slope wash. The feature is considered to be a fault rather than an unconformity because the younger beds on the northeast side are generally more deformed than are the older beds on the southwest side, and in some places the younger beds strike toward the older ones. In the map area, beds equivalent to those southwest of the fault are absent or unrecognized northeast of the fault.

The fault that trends northwest across the Williams Hill quadrangle from sec. 4, T. 23 S., R. 9 E., to sec. 19, T. 22 S., R. 9 E., is generally marked by a zone of crushed and contorted rock 500 or more feet wide. This fault extends at least $31 / 2$ miles farther northwest into the Espinosa Canyon quadrangle (Durham, 1964). Data from wells suggest that the basement complex may be downdropped on the northeast side of this fault (structure section $B^{\prime}-B^{\prime \prime}$, pl. 2).

\section{FOLDS}

Closely spaced folds are present in the Monterey Shale at many places in the map area. The pattern of folding in each fault block suggests that the folds are features restricted to the block in which they occur, rather than parts of larger folds offset by faults. The limbs of folds are at many places vertical or nearly vertical. In the $\mathrm{NW} 1 / 4$ sec. 8, T. 23 S., R. 7 E., the upper part of an anticline is overturned in such a manner that beds exposed high on the ridges on the south limb are overturned, although the beds on both limbs are upright where exposed lower in the intervening canyons. Beds near the axial plane of steep-limbed folds in the Monterey Shale are commonly crushed and contorted (fig. 5).

\section{ECONOMIC GEOLOGY}

\section{PETROLEUM}

Seventeen unsuccessful wells were drilled for oil in the map area before 1963 (table 2). The wells are mainly located in the southeast quarter of the Williams Hill quadrangle, where the structurally high basement complex is overlain in the subsurface by sandstone beds. Most of the drilling was done from 1956 through 1958. 


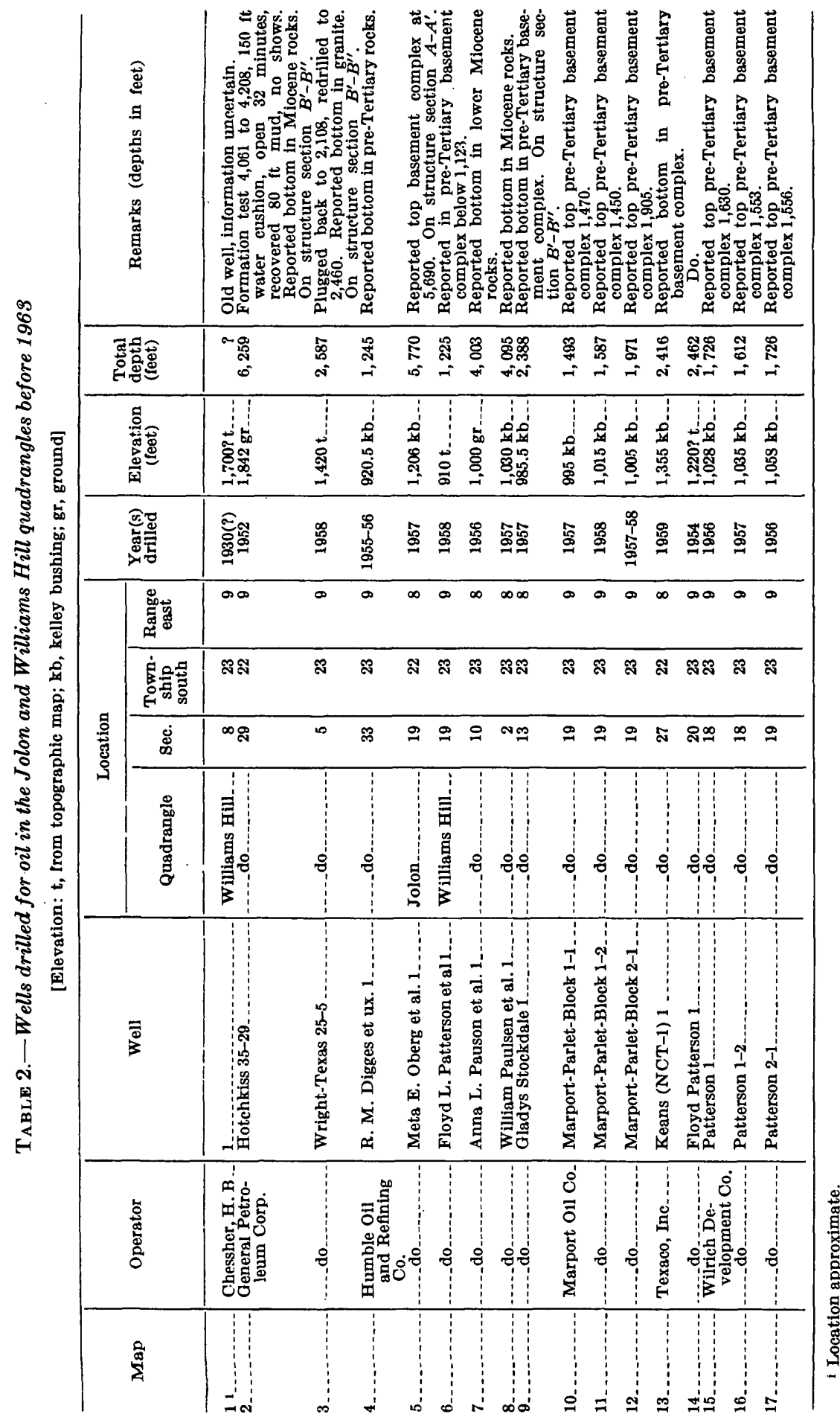




\section{GOLD}

Placer gold of little economic importance occurs in the alluvial deposits along the San Antonio and Nacimiento River (Davis, 1912, p. 696). Chinese workmen, who washed the gravels of the San Antonio River near Jolon for several years before 1887, produced gold in small quantities (Hill, 1923, p. 325).

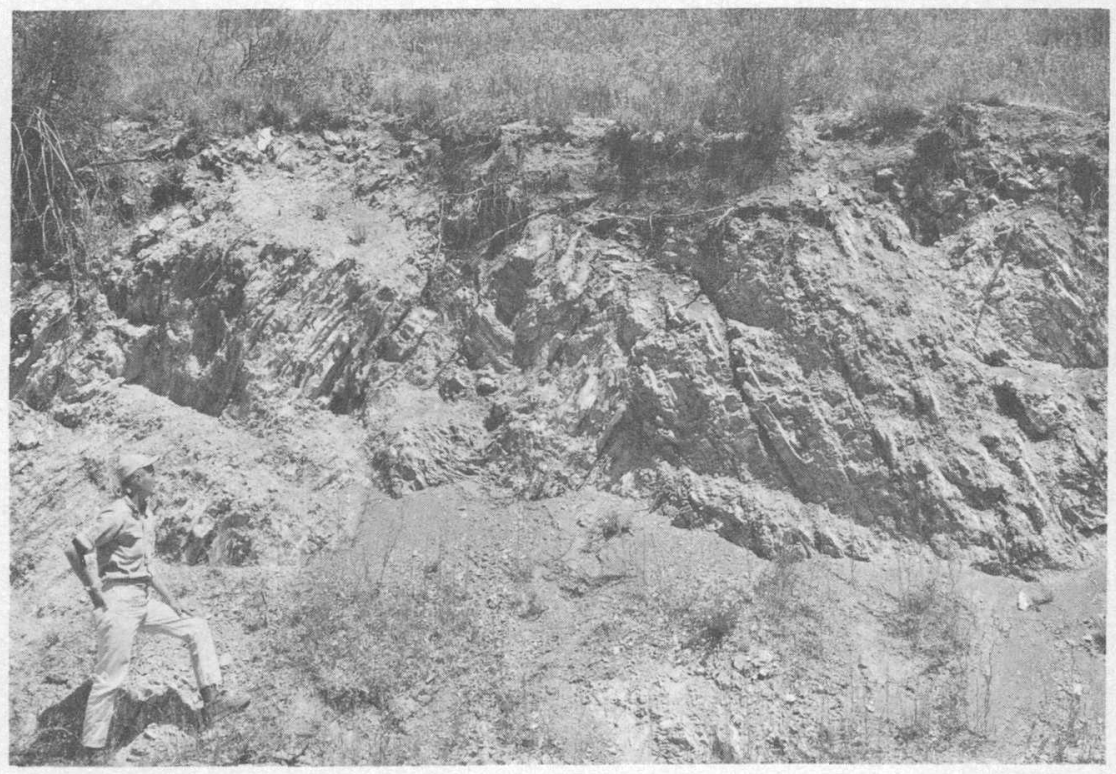

Figure 5.-Anticline in the Monterey Shale exposed in Sam Jones Canyon in the NW $1 / 4$ SE $1 / 4$ sec. 30, T. 23 S., R. 8 E. The beds in the heart of the fold are broken and contorted.

TABLE 3.-Fossil localities

[Projected sections are marked by an asterisk (*)]

\begin{tabular}{|c|c|c|c|c|c|c|c|}
\hline \multirow{2}{*}{ USGS } & \multicolumn{4}{|c|}{ Location } & \multirow{2}{*}{ Member or formation } & \multicolumn{2}{|c|}{ Ty pes of fossils } \\
\hline & Quadrangle & Sec. & $\begin{array}{l}\text { Town- } \\
\text { ship } \\
\text { south }\end{array}$ & $\begin{array}{c}\text { Range } \\
\text { east }\end{array}$ & & $\begin{array}{l}\text { Foram- } \\
\text { inifera }\end{array}$ & $\begin{array}{l}\text { Mol- } \\
\text { lusks }\end{array}$ \\
\hline Mf628_... & Jolon _... & 22 & 23 & 7 & $\begin{array}{l}\text { Sandholdt Member } \\
\text { of Monterey } \\
\text { Shale. }\end{array}$ & $x$ & \\
\hline Mf722_... & _.... do & $* 32$ & 23 & 7 & $\begin{array}{l}\text { Unnamed formation, } \\
\text { of Paleocene(?) } \\
\text { age. }\end{array}$ & $x$ & \\
\hline M1453_.- & - do do & *36 & 23 & 7 & Vaqueros Formation & & $x$ \\
\hline $\begin{array}{l}\text { M1454_- } \\
\text { M1455_- }\end{array}$ & $\begin{array}{l}\text { Williams } \\
\text { Hill. }\end{array}$ & $\begin{array}{r}6 \\
* 36\end{array}$ & $\begin{array}{l}24 \\
23\end{array}$ & $\begin{array}{l}8 \\
8\end{array}$ & $\begin{array}{l}\text { Unnamed formation } \\
\text { of Pliocene age. }\end{array}$ & & x \\
\hline
\end{tabular}




\section{REFERENCES CITED}

Blake, W. P., 1855, Notice of remarkable strata containing the remains of Infusoria and Polythalmia in the Tertiary formation of Monterey, California : Acad. Nat. Sci. Philadelphia Proc., v. 7, p. 328-331 [1856].

Bramlette, M. N., and Daviess, S. N., 1944, Geology and oil possibilities of the Salinas Valley, California : U.S. Geol. Survey Oil and Gas Inv. (Prelim.) Map 24.

Chayes, Felix, 1949, A simple point counter for thin-section analysis: Am. Mineralogist, $\nabla .34$, nos. 1-2, p. 1-11.

Clark, B. L., 1930, Tectonics of the Coast Ranges of middle California : Geol. Soc. America Bull., v. 41, no. 4, p. 747-828.

1932, Age of primary faulting in the Coast Ranges of California: Jour. Geology, v. 40, no. 5, p. 385-401.

1940, Two new Pliocene formations in California [abs.]: Geol. Soc. America Bull., v. 51, no. 12, pt. 2, p. 1956-1957.

Curtis, G. H., Evernden, J. F., and Lipson, J. I., 1958, Age determination of some granitic rocks in California by the potassium-argon method: California Div. Mines Spec. Rept. 54, 16 p.

Davis, C. H., 1912, The Los Burros mining district [California]: Mining and Sci. Press, v. 104, p. 696-698.

Durham, D. L., 1963, Geology of the Reliz Canyon, Thompson Canyon, and San Lucas quadrangles, Monterey County, California : U.S. Geol. Surrey Bull., 1141-Q, $41 \mathrm{p}$.

1964, Geology of the Cosio Knob and Espinosa Canyon quadrangles, Monterey County, California: U.S. Geol. Survey Bull. 1161-H, 29 p.

English, W. A., 1918, Geology and oil prospects of the Salinas Valley-Parkfield area, California : U.S. Geol. Survey Bull. 691-H, p. 219-250.

Fairbanks, H. W., 1893, Notes on a further study of the pre-Cretaceous rocks of the California Coast Ranges: Am. Geologist, v. 11, p. 69-84.

- 1894, Geology of northern Ventura, Santa Barbara, San Luis Obispo, Monterey, and San Benito Counties [California]: California Mining Bur. 12th Rept., State Mineralogist, p. 493-526.

- 1898, Geology of a portion of the southern coast ranges: Jour. Geology, v. 6, p. 551-576.

1900, Monterey County, in Watts, W. L., Oil and gas yielding formations of California : California Mining Bur. Bull. 19, pt. 8, chap. 1, p. 143-146.

1904, Description of the San Luis quadrangle [California]: U.S. Geol. Survey Geol. Atlas, Folio 101.

Hamlin, Homer, 1904, Water resources of Salinas Valley, California: U.S. Geol. Survey Water-Supply Paper 89, $91 \mathrm{p}$.

Hill, J. M., 1923, The Los Burros district, Monterey County, California : U.S. Geol. Survey Bull. 735-J, p. 323-329.

Holmes, Arthur, 1960, A revised geological time-scale: Edinburgh Geol. Soc. Trans., v. 17, pt. 3, p. 183-216.

Kilkenny, J. E., 1948, Geology and exploration for oil in Salinas Valley, Callfornia : Am. Assoc. Petroleum Geologists Bull., v. 32, no. 12, p. 2254-2268.

Lawson, A. C., 1893, The geology of Carmelo Bay [California] : California Univ. Dept. Geology Bull., v. 1, no. 1, p. 1-59.

Lawson, A. C., and others, 1908, The California earthquake of April 18, 1906. Report of the State Earthquake Investigation Commission: Carnegie Inst. Washington Pub. 87, v. 1, pt. 1, 254 p. 
Nutter, E. H., 1901, Sketch of the geology of the Salinas Valley, California : Jour. Geology, v. 9, p. 330-336.

Pike, R. W., 1926, Geological studies in the San Antonio and Nacimiento River valleys, Monterey County, California [abs.] : Geol. Soc. America Bull., v. 37, no. 1, p. 213.

Reed, R. D., 1925, The post-Monterey disturbance in the Salinas Valley, California : Jour. Geology, v. 33, no. 6, p. 588-607.

Taliaferro, N. L., 1943a, Geologic history and structure of the central Coast Ranges of California: California Div. Mines Bull. 118, p. 119-163.

— 1943b, Bradley-San Miguel district [California] : California Div. Mines Bull. 118, p. $456-462$.

- 1944, Cretaceous and Paleocene of Santa Lucia Range, California: Am. Assoc. Petroleum Geologists Bull., v. 28, no. 4, p. 449-521.

Trask, P. D., 1926, Geology of the Point Sur quadrangle, California : California Univ., Dept. Geol. Sci. Bull., v. 16, no. 6, p. 119-186.

Vander Leck, Lawrence, 1921, Petroleum resources of California, with special reference to unproved areas: California Mining Bur. Bull. 89, $186 \mathrm{p}$.

Whitney, J. D., 1865, Geological Survey of California, Report of progress and synopsis of the field work from 1860 to 1864: California Geol. Survey, Geology, v. 1, 498 p.

Wiedey, L. W., 1928, Notes on the Vaqueros and Temblor formations of the California Miocene with descriptions of new species: San Diego Soc. Nat. History Trans., v. 5, no. 10, p. 95-182. 